\title{
Euskadiko Kooperatiben Lege berria ${ }^{\&}$
}

\section{The new Law on Cooperatives in the Basque Country}

\author{
Aitor Bengoetxea Alkorta*1\&\&, Itziar Villafáñez Pérez ${ }^{2 \& \& \&}$
}

${ }^{1}$ Lanaren eta Gizarte Segurantzaren Zuzenbideko Irakasle Agregatua.

GEZKI Institutuko Zuzendaria (Gizarte Ekonomia eta Zuzenbide Kooperatiboaren Institutua).

Universidad del País Vasco/Euskal Herriko Unibertsitatea (UPV/EHU)

${ }^{2}$ Merkataritza Zuzenbideko irakasle atxikia. GEZKIko ikertzailea.

Universidad del País Vasco/Euskal Herriko Unibertsitatea (UPV/EHU)

\begin{abstract}
Laburpena: 2019ko abenduaren 20an Eusko Legebiltzarrak 11/2019 Legea, Euskadiko Kooperatibei Buruzkoa, onartu zuen, lurraldeko kooperatibentzako indarrean dagoen araudia bihurtu delarik. Orokorrean ordezkatu duen legearen izpiritua, joera eta edukia mantentzen dituen arren, arlo ezberdinetan berrikuntza nabarmenak eta interpretazio-arazoak planteatzen zituzten gaietan argibideak ere ekarri ditu, zalantzarik gabe eztabaidagarriak izan daitezkeenak. Kooperatiben inguruko azterketa juridikoan aurrekoen azterketak berebiziko interesa du, bereziki Euskadiko kooperatiben erreferentzialtasuna aintzat hartuta. Lan honek, beraz, lege berriak jasotako aspektu eta berrikuntza nagusiak errepasatzen ditu bere atal ezberdinak jarraituz, azpimarragarrienak diren alderdiei arreta berezia eskainiz (hala nola, genero berdintasunaren bidean jasotako xedapenak, digitalizazioari buruzkoak, administratzaileen betebeharrei dagozkienak, bazkideen erantzukizunaren araubidearen arauketa edota lan elkartuko kooperatiben araubidea) beti ere begirada kritikoa mantenduz.
\end{abstract}

Hitz gakoak: Kooperatiben legea, Euskadi, batzar orokorra, administratzaileen betebeharrak, bazkideen erantzukizuna, lan elkartuko kooperatibak.

Abstract: On December 20, 2019, the Basque Parliament approved Law 11/2019, on Cooperatives in the Basque Country, which has become the current regulation for cooperatives in the territory. While it retains the spirit, tendencies, and content of the law it has replaced, it has also provided significant innovations and interpretation issues in various areas, which can certainly be debatable. In the legal analysis of cooperatives, the study of those issues is of particular interest, especially in view of the importance of Basque cooperatives in the world. This work therefore reviews the main aspects and innovations of the new law, focusing on the most important aspects (such as the provisions on gender equality, digitalisation, the duties of administrators, the regulation of the liability regime of members, or news on hiring employees in worker cooperatives) always keeping a critical eye.

Keywords: Cooperatives law; Basque Country; general assembly; directors' duties; members' liability; worker cooperatives.

Econlit gakoak: $\mathrm{K} 22, \mathrm{~K} 31, \mathrm{P} 13, \mathrm{~J} 54$.

\& Artikulu hau oinarritua dago egileek idatzitako beste artikulu honetan: Bengoetxea Alkorta, A. eta Villafáñez Pérez, I. (2020). Basque legislation on cooperatives in light of the new basque cooperative law, International Journal of Cooperative Law, issue III.

\&\& "Gizarte Ekonomia eta bere Zuzenbidea», IT 1327-19, Ikerketa Taldearen baitan egindako lana.

\&\&\& «La ética empresarial en las diversas manifestaciones del Derecho Mercantil», ikerketa taldea, IT 1146-16. «Nuevas tecnologías, transformación de mercados y Derecho de Competencia» ikerketa proiektuaren (Zientzia, Berrikuntza eta Unibertsitate Ministerioak eta Eskualdeen Garapenerako Europako Funtsak finantzaturikoa; RTI2018-094201-B-C21) eta «El transporte ante el desarrollo tecnológico y la globalización: nuevos desafíos jurídicos del sector marítimo y portuario", ikerketa proiektuaren (Zientza et berrikuntza Ministeritzak eta Lurralde Garapenerako Europako Funtsak finantzatutakoa; PID2019107204GB-C32/ AEI / 10.13039/501100011033) baitan egindako lana.

* Harremanetan jartzeko/Corresponding author: Aitor Bengoetxea Alkorta. GEZKI Institutuko Zuzendaria (Gizarte Ekonomia eta Zuzenbide Kooperatiboaren Institutua). Universidad del País Vasco/Euskal Herriko Unibertsitatea (UPV/EHU) aitor.bengoetxea@ehu.eus - https://orcid.org/0000-0002-0947-4793

Nola aipatu/How to cite: Bengoetxea Alkorta, Aitor; Villafáñez Pérez, Itziar (2020). «Euskadiko Kooperatiben Lege berria», GlZAEKOA - Revista Vasca de Economía Social, 17, 197-224. (https://doi.org/10.1387/gizaekoa.22233).

Jasoa: 16/06/2020; onartua: 30/06/2020

ISSN 1698-7446 - elSSN 2444-3107 / (c) 2020 UPV/EHU

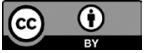

Obra hau Creative Commons Atribución 4.0 Internacional-en

lizentziapean dago 


\section{Sarrera}

Euskadiko Autonomi Erkidegoak eskumen esklusiboa dauka Kooperatiben gaian (Euskadiko Autonomia Estatutua, 3/1979 Lege Organikoa, abenduak 18koa, 10.23 art.). Eskumen hori baliatuta, legegile autonomikoak Euskadiko Kooperatiben Legea sortu du, 11/2019 Legea, abenduak 20koa (EKL).

Kooperatiba lege berriak, teknikoki, orain arteko kooperatiba legediaren aldatze eta bateratze gisa aurkezten du bere burua. Esan genezake legea bere aurrekarietan oinarritzen dela, euskal kooperatiben araubide juridikoaren aldaketa sakonik gabe. Hala ere, lan honetan ikusiko dugun bezala, lege berria bateratze hutsaz haratago doa, garrantzitsuak diren berrikuntzak ekarriz.

Bateratu beharreko lege nagusia 4/1993 Legea da, ekainak 24koa, Euskadiko kooperatibei buruzkoa ${ }^{1}$. Lege hori indarrean egon da azken hamarkadetan. Hamarkada horietan testuinguru sozioekonomikoa asko aldatu da, besteak beste globalizazio ekonomikoa nagusitu da, eta kooperatibak testuinguru berri horretara egokitu behar izan dira. Horregatik komeni zen legedi kooperatiboaren eguneratze teknikoa, aldi berean segurtasun juridikoa eskainiz, kooperatibak bere bazkideekin dituen harremanetan, eta baita ere bazkide ez diren hirugarrenekin.

Erreferentziako parametro gisa, euskal kooperatiben lege berriak aintzat hartu du zuzenbide konparatuaren bilakaera, bereziki merkatal arloan, eta, noski, alor kooperatiboan.

Legea sortzeko ibilbidea luzea izan da, 2017an hasi baitzen, lehen zirriborroarekin. Amaiera 2019ko abenduaren 20an izan zen, legebiltzarrean aurkeztutako lege-proiektua aurrera atera zenean lau talde parlamentarioen aldeko botoarekin (Euzko Abertzaleak-Nacionalistas Vascos; Euskal Herria Bildu; Socialistas Vascos-Euskal Sozialistak; eta Popular Vasco-Euskal Talde Popularra), eta beste talde baten abstentzioarekin (Elkarrekin Podemos).

Erronka nagusia da legedi kooperatiboa eguneratzea nortasun kooperatiboa galdu gabe. Nortasun edo identitate hori Nazioarteko Aliantza Kooperatiboak (NAK), mundu mailako mugimendu kooperatiboa ordezkatzen duen gobernuz kanpoko erakundea, honela definitu du: borondatez elkartu diren pertsonen elkarte autonomoa, beren beharrizan eta asmo komunak asetzeko, arlo ekonomiko, sozial eta kulturalean, demokratikoki kudeaturiko eta jabetza komuneko enpresa baten bitartez. Gai honetan, oso balorazio positiboa merezi du, gure ustez, lege berriak lehen aldiz espresuki aipatzea Nazioarteko Aliantza Kooperatiboa, berak definitutako printzipio eta balio kooperatiboekin, euskal kooperatiba legediaren esparru unibertsal inspiratzaile gisa.

1 Baita ere azpimarratu behar da 58/2005 Dekretua, martxoak 29koa, Kooperatiba Legearen Erregelamendua jasotzen duena. 
Era berean, positiboa iruditzen zaigu lege berriak kooperatiba gizarte ekonomiaren testuinguruan kokatzea, 5/2011 Legeak, martxoaren 29koa, Gizarte Ekonomiari buruzkoak dioenarekin bat etorriz, lege honek kooperatiba ezartzen baitu gizarte ekonomiaren barruko enpresa mota nagusi gisa, pertsona kapitalaren aurretik lehenesten duen sektore ekonomiko horretan.

\section{Xedapen orokorrak}

Kooperatibaren kontzeptua 4/1993 Legekoa da, berbera: Kooperatiba da enpresa bat garatzen duen sozietatea, zeinaren lehentasuneko helburua baita bere kideen jarduera ekonomiko eta sozialak sustatzea eta haien beharrak beren parte-hartze aktiboaren bitartez asetzea, kooperatibismoaren printzipioak betez eta inguruko komunitateari erantzunez (EKLko 1.1 art.).

Ondoren, gorago aurreratu dugun bezala, gure ustez oso egokia den berrikuntza dator, legeak euskal kooperatiba Nazioarteko Aliantza Kooperatiboaren testuinguruan kokatzen duenean, ondokoa adieraziz: Kooperatibak Nazioarteko Kooperatiba Aliantzaren kooperatiba-printzipioetara, zeinak lege honen esparruan aplikatuko baitira, egokitu beharko ditu bere egitura eta funtzionamendua (1.2 art.).

Berrikuntza egokia iruditzen zaigu, besteak beste, kooperatiba faltsuen aurkako borrokan lagundu dezakeelako, argi geratzen baita ezinbestekoa dela euskal kooperatiben egitura eta funtzionamendua NAKaren printzipioekin bat etorri behar direla, bestela, kooperatiba faltsu baten aurrean geundeke.

Printzipio horiek kooperatibek garatu ditzaketen jarduera ekonomikoak baldintzatzen dituzte. Izan ere, jarduera ekonomikoa edozein izan daiteke, printzipio kooperatiboen kontrakoa izatean oinarrituriko legezko debekurik ez badago (1.3 art.).

Legeak kooperatibaren ezinbesteko autonomia azpimarratzen du, edozein motako entitate publiko edo pribatuen aurrean. NAKaren laugarren printzipio kooperatiboa da.

Gutxieneko kapital soziala 3.000 eurokoa da (4. art.). Kopuru hori zentzuduna dirudi, lehendik eskatzen zena da, eta orokorrean erantzukizun mugatuko sozietateak sortzeko eskatzen dena da ere (KSL 4.1 art.) ${ }^{2}$.

2 Kapitalezko Sozietateen Legea (KSL): 1/2010 Errege Dekretu Legegilea, uztailaren 2koa.

KSLaren 4.2 eta 4 bis artikuluek sozietate mota hauek 3000 euroko kapital sozial minimoaren betekizuna bete gabe sortzea ahalbidetzearen kalterik gabe, kasu honetan bertan jasotako araubide berezia aplikatuko delarik. 
4/1993 Legeak zioen moduan, lege berriak ere dio Kooperatiben egoitza soziala bere bazkideekiko jarduera gehienak egiten dituen lekuan edo administrazio-kudeaketa eta enpresa-zuzendaritza zentralizatzen dituen lekuan kokatuko dela, betiere Euskadiko Autonomia Erkidegoaren barruan (3. art.). Honekin lotuta, azken xedapenetako lehenengoak dio kooperatibei EKL aplikatuko zaiela Euskal Autonomia Erkidegoan baldin badute sozietatearen egoitza, eta batez ere lurralde horretan betetzen badute beren kooperatiba-jarduera.

Jarduera kooperatiboaren esparruaren inguruan, 1.1 art.ak dioenean bere lehentasuneko helburua izan behar dela bere kideen jarduera ekonomiko eta sozialak sustatzea eta haien beharrak beren parte-hartze aktiboaren bitartez asetzea, kooperatiba bazkideak ez diren hirugarren pertsonekin jardutea baimentzen ari da. Horixe da 5. art.an espresuki aurreikusten den aukera, betiere lege honetan eta kooperatibaren estatutuetan ezarritakoaren mugetan, kooperatiba motaren arabera.

\section{Kooperatibak sortzea eta Euskadiko kooperatiben Erregistroa}

\subsection{Kooperatiba sortzea}

Ez dago berrikuntza nabarmenik gai honetan, gakoak dira batzar sortzailea osatzen duten pertsona sustatzaileak, eta batzar horrek onartu beharreko estatutuak.

Eskritura publiko bidez sortuko da kooperatiba. Agiri hori emateko, bi hilabeteko epea izango da, batzar sortzailea sortu denetik aurrera kontaturik, edo, hala badagokio, sozietatearen estatutu-proiektua kalifikatzen denetik aurrera kontaturik. Ondoren, Euskadiko Kooperatiben Erregistroan inskribatuko da, eta une horretatik aurrera nortasun juridikoa izango du (11. art.).

Berrikuntza interesgarri gisa, estatutuen gutxieneko edukian, azpimarratu nahi ditugu bazkideen informaziorako eskubidea errespetatzeko ezarritako bermeak eta organoak (13.1 o art.). Berrikuntza positiboa, bazkideak kooperatibaren jardueraz ongi informatuta egotea ezinbesteko baldintza baita, kooperatibak behar bezala funtzionatzeko.

Berrikuntza egokia iruditzen zaigu, halaber, estatutuen gutxieneko edukiaren baitan, ondoko aurreikuspena: 50 bazkide baino gehiago duten sozietate kooperatiboek kooperatibaren delituei aurrea hartzeko eredu bat egingo dute, eta eredu horren jarraipena egiteko mekanismoak ezarriko dituzte. Halaber, berariazko baliabideak jarri beharko dituzte kooperatibak bortizkeria matxistarik gabeko eremuak izan daitezen (13.1 q art.). 


\subsection{Euskadiko Kooperatiben Erregistroa}

Gorago aipatu dugun moduan, kooperatiba sortzeko ezinbestekoa da Euskadiko Kooperatiben Erregistroan inskribatzea, eta hortik aurrera izango du kooperatibak nortasun juridikoa.

Erregistroaren ezaugarri nagusiak 15. art.an adierazten dira: Euskadiko Kooperatiben Erregistroa erregistro publikoa da, Eusko Jaurlaritzan lan-arloko eskumena duen sailari atxikia, eta organo-egitura bateratua $d u$.

Inskribatu beharreko egintza nagusien inskripzioak sortze-izaera edukiko du (kooperatiba sortzea, fusioa, zatitzea, desegitea, berrindartzea, eta kooperatiba bihurtzea). Gainerako kasuetan, erregistroan inskribatzeak izaera deklaratiboa izango du.

Badago berrikuntza bat, aurrerapen teknologikoekin bat datorrena, behartzen duena Erregistroa bitarteko elektroniko, informatiko eta telematikoen erabilpena sustatzera, herritarrekin eta entitateekin dituen harremanetan (16.3 art.).

\section{Bazkideak eta hauen araubide juridikoa}

Bazkideei dagokienez, EKL berriak ez du 1993ko Legearekiko aldaketa handirik jasotzen. Honela, kooperatiben legediak bazkideen izaerari (pertsona fisiko zein juridikoak, publikoak eta pribatuak...) eta bazkide motei (kooperatzaileak, ez-aktibo edo ez-erabiltzaileak, laguntzaileak, kooperatiba mistoetako bazkide bereziak, iraupen jakin baterako harremana duten bazkideak...) buruzko arauketa mantentzen du, berrikuntza bezala aurrekoei eszedentziadun bazkideak gehituz, hau da, jarduera aldi baterako utzi duten bazkideak, orokorrean bazkide mota hau egoteko aukera eta, bere kasuan, bere araubidea, estatutuetan ezarriko direlarik $(31.4 \text { art.) })^{3}$, edozein kasutan batzar orokorrean izan ditzaketen bozkak mugatuta egongo direlarik (37.4 art.).

Gutxi dira ere bazkide izaera eskuratzeari eta galtzeari buruzko berrikuntzak. Bazkideen eskubideak hobetze aldera, administratzaileek bazkideen bajak gehienez ere horretarako aurreabisua jakinarazten denetik 3 hilabeteko epean formalizatzeko beharra jasotzen da, epe hori igarota jakinarazpenik egin ez bada bazkidearen baja bidezkotzat joko delarik (26.6 art.). Bestalde, 30.2 artikuluko kasuetan, hau da, kooperatibaren bideragarritasun ekonomikoa arriskuan jar dezaketen arrazoi larriak direla eta bazkide langileen edo lan-baz-

${ }^{3}$ EKL 31.4 art: Sozietatearen estatutuetan, jarduera aldi baterako utzi duen bazkidearen figura erregulatu ahal izango da, hau da, eszedentziadunarena. Bazkide horri dagozkion eskubideak eta betebeharrak estatutuetan ezarriko dira. 
kideen baja erabakitzen denean, hauen nahitaezko ekarpenak gehienez 2 urteko epean hilero bueltatzea posible izango da (aurretik, borondateko ekarpenak eta nahitaezkoak berehala bueltatu behar ziren $)^{4}$.

Azkenik, bazkideen eskubide eta betebeharrei dagokienez, 29 artikuluak, bazkideen babes handiagoa bilatuz, diziplina-arauak estatutuetan jasota egon beharko dutela adierazten du. Hortaz, bazkideei ezingo zaie estatutuetan jasota ez dagoen zigorrik ezarri, 1993eko legediaren arabera arau-hauste arinak barne erregelamenduan arautu zitezkeen bitartean. Helburu berarekin, arau-hausteen preskripzio-epearen zenbaketaren hasierari dagokionez, hau arau-haustearen eguna izango dela jasotzen da (edo arauhaustearen bukaerako eguna, jarraitua edo iraunkorra izan denean), aurretik administratzaileek horren berri zutenean hasten zelarik epea zenbatzen. Zentzu honetan, beraz, EKLak bazkideen bermeak handitzen ditu.

Bestalde, bazkideek kooperatiben jardueran parte hartzeko oinarrizko betebeharra mantentzen da, hau kooperatibaren jardueran zuzenean parte hartuz edo beste entitate batzuetan parte hartuz gauzatu daitekeela gehituz, aukera hau estatutuetan jasota dagoenean, eta beti ere kooperatibak entitate horiekiko lankidetzan diharduenean, haietan parte hartzen duenean edo helburu sozialari lotutako interes berezia duenean. Edozein kasutan, salbuespen batzuekin, kooperatibako gutxiengo batek baino ezingo du beste entitate horietan partaidetza izan (22.c art.). Hau guztia, ordea, ez da kooperatibei buruzko gure legediaren berrikuntza bat, aurretik ere Euskadiko Kooperatiben Legearen Erregelamenduan (1.1 art.) jasota zegoelarik. EKLak lege-lerruna eman dio aukera honi.

\section{Kooperatiben organoak}

EKLak 1993ko Legeak aurreikusitako organoak mantentzen ditu, kasuren batean berrikuntza interesgarriekin. Honela, batzar orokorra eta administrazio-organoa edozein kasutan beharrezkoak izango dira, eta 100 bazkide edo gehiago dituzten kooperatibetan baita zaintza-batzordea ere. Estatutuetan sozietate-kontseilua (EKLren arabera dagoeneko ez delarik beharrezkoa kooperatibak 50 bazkide langile edo lan-bazkide baino gehiago izatea, justifikaziorik ez zuen muga kenduz; 57. art.) eta errekurtso batzordea edota bestelako organoak aurreikusi litezke (32. art.).

${ }^{4}$ Edonola ere, artikulu berak hurrengoa gehitzen du: Nolanahi ere, kooperatibak objektibatu daitezkeen baliabide ekonomikoak dituenean, nahitaezko ekarpenak aribideko ekitaldi ekonomikoan itzuli beharko ditu.Kooperatiba uzten duten bazkideak 60.1.b artikuluan xedatutako ekarpenen titularrak badira eta kooperatibak ez badu erabakitzen ekarpen horiek berehala itzultzea, kooperatiban segitzen duten bazkide guztiek berehala eskuratu beharko dituzte ekarpen horiek, batzar orokorrak erabakitzen duen baldintzetan. 
Arlo honetan EKLak ekarritako aldaketak funtsean batzar orokorrari eta administrazioari dagozkion heinean ${ }^{5}$, hurrengo orrialdeetan hauen erregimenean zentratuko gara.

Bereziki azpimarragarria da kooperatibaren organo guztietan emakumeen eta gizonen presentzia orekatua izateko ahaleginak egiteko betebeharra, genero-berdintasuneko neurriak ezarriz, eta bereziki, bizitza pertsonala, familia eta lana bateratzeari begirakoa (32.4 art.). Zalantzarik gabe, legedian genero-ikuspegia txertatzea eta indartzea beharrezkoa eta txalogarria $\mathrm{da}^{6}$. Hala ere, aurreikuspen honen balorazio arin bat egiterakoan ezin ditugu hurrengoak aipatu gabe utzi: Lehenengo eta behin, ohikoa den bezala, nabarmena da legegileak oraindik ere ez duela izan beharrezko ausardia berdintasunaren inguruan benetako betebeharrak ezartzeko. Bestalde, holako aurreikuspenek berdintasuna lortzeko bidean urratsak emateko oso baliagarriak diren arren, ezin daiteke ahaztu horiek jasoko ez balira ere ordenamendu juridikoak dagoeneko generoagatiko bereizkeria (beste bereizkeria mota batzuk bezala) debekatzen duela. Era berean, genero-berdintasuna kooperatiben printzipioetan eta sozietate hauen interes sozialean edota ordena publiko kooperatiboan ere barneratuta dagoela babestu dela ere gogoratu behar $\mathrm{da}^{7}$. Aldi berean, hurrengo ataletan jasotakoari lotuz, teknologia berriek eta digitalizazioak kooperatiben organoetan emakumezkoen parte hartzea errazteko planteatu ditzaketen aukerak kontuan izan behar dira (eta baita honen arrisku guztiak). Azkenik, bizitzaren atal ezberdinak bateratzeari buruzko aipamenari dagokionez, orokorrean egiten den aipamena erabili bada ere (bizitza pertsonala, familia eta lana), testuinguru honetan bizitza sozialari erreferentzia ere egitea bereziki egokia litzateke, emakumezkoek sozietatearen organoetan eta erabaki guneetan berdintasunez parte hartzearen dimentsioarentzat ere esamolde espezifikoa erabiliaz.

\subsection{Batzar orokorra}

Organo honen arauketari dagokionez, EKLak jasotako hainbat berrikuntza egokitzapenak edo hobekuntza teknikoak dira, horiek izan ditzaketen garrantzia praktikoaren kalterik gabe. Esaterako, batzar orokorra eki-

5 Zaintza-batzordeari dagokionez, aipagarria da kontabilitate-euskarrien eta ekitaldiaren emaitzaren gain dituen kontrol ahalmenak indartzea.

${ }^{6}$ Legearen gaztelerazko bertsioan ere ikuspegi honetatik inklusiboagoa den hizkera erabiltzeko saiakera azpimarragarria da, nahiz eta legearen onarpen prozedura aztertuta legegileak azken momentura arte honekiko sentsibilitate handia izan ez zuela onartu behar den.

7 Besteak beste, Elio (2006, 45-46 orr.), Senent (2011) edo, kooperatibaren interes sozialari dagokionez, Villafáñez (2017). 
taldia bukatu eta hurrengo 6 hilabeteetan bildu behar dela agintzen da, aurretik epe hori batzar orokorraren deialdiari zegokiolarik. Hala ere, badaude bereziki azpimarragarriak diren aspektuak.

Teknologia berrien erabilpenari buruzko arauketaren garapen nabarmena organo honen arauketan sartutako berrikuntza azpimarragarrienetarikoa da. Honela, teknologia berrien berariazko aipamena egiten da bai batzar orokorraren deialdiari dagokionez (webgune korporatiboan honen publizitatea jasotzea, eta bazkideei deialdiaren berri emateko alarma-sistema baten kudeaketa telematikoa egiteko aukera; 35.5 art. $^{8}$ ), bai honetan parte hartzeari dagokionez (bideokonferentzia edo antzeko sistemen bidez; 36.1 art. $^{9}$ ), bai boto-eskubidea egikaritzeari dagokionez (bide telematikoen bidez bozkatzea; 37.6 art. ${ }^{10}$ ). Kooperatiben organoen funtzionamenduan teknologia berrien erabilpena hedatzen doan heinean, hauen arauketa naturala dela baieztatu beharra dago. Ikuspegi honetatik, aspektu honen arauketaren garapena positiboa delakoan gaude. Kontuan izan behar da, izan ditzakeen eragozpenak ahaztu gabe (besteak beste, norbanakoen arteko harreman zuzenen garrantzia, kooperatibetan bereziki garrantzitsuena izan litekeena), teknologia berriek eta digitalizazioak kooperatiben organoetan parte hartzea ere erraztu lezaketela (bereziki garrantzitsua izan daitekeena kontziliazio arazoei aurre egiteko edo haien izaera dela eta bazkideak geografikoki bananduta egon ohi diren kooperatibetan - esaterako, garraio-kooperatibak-). Hala ere, legearen testua irakurtzean sortzen den inpresioa guztiz birtualak diren bilerak egitea aurreikusten ez dela da, es-

${ }^{8}$ EKL 35.5.III eta IV art.: Kooperatibak web-orri korporatibo bat duenean, sozietatearen weborrian iragarriko da batzar orokorraren deialdia, betiere batzar orokorrak hartu badu web-orria sortzeko erabakia eta Euskadiko Kooperatiben Erregistroan kooperatibarentzat irekitako orrian jasota badago erabaki hori. Horrela bada, ez da aplikatu beharko aurreko paragrafoan ezarritako betebeharra. Deialdia bazkide guztiengana helduko dela bermatzeko, legean xedatutakoez bestelako mekanismo batzuk ezarri ahal izango dira sozietatearen estatutuetan, eta sozietateari exijitu ahal izango zaio alertasistema telematiko bat ezar dezala bazkideentzat batzarrerako deialdia sozietatearen web-orrian egiten duenean. Hala ere EKLk ez du web-orri korporatiboaren arauketarik, analogia erabilita KSLko arauketara jo litekeelarik, gure ustez konponbide hau ez delarik guztiz egokia.

${ }^{9}$ EKL 36.1.II eta III art.: Estatutuetan, aukera eman ahal izango da geografikoki urruti dauden bazkideek parte har dezaten erabakiak baliozkotasunez hartzen eta beren nabiak adierazten bideokonferentziaren bidez edo irudiaren eta soinuaren bi noranzko eta aldibereko komunikazioa, eta ikusizko, entzumenezko eta ahozko elkarrekintza ahalbidetuko duen antzeko sistema baten bidez.

Bazkideren batek aurreko paragrafoan adierazitako moduan parte hartzen badu batzar orokorrean, batzarraren idazkariak, hartutako erabakiak baliozkoak izateko exijituriko baldintza guztiekin batera, espresuki jasoko du borondate hori aktan, baita bazkide horren izen-abizenak eta parte hartzeko erabili den bidea ere.

${ }^{10}$ EKL 37.6 art.: Estatutuetan ezarri ahal izango dira bozketak telematikoki egiteko prozedura, baldintzak eta betekizunak, kontuan hartuta botoaren konfidentzialtasuna bermatuko behar dela nahitaez. 
presuki debekatzen ez den arren. Zentzu honetan, egokiagoa izan liteke bilerak egiteko orokorrean bideokonferentzia edo antzeko sistemak erabiltzea baimentzea, beti ere bilerok modu honetan egiteko bermeak azpimarratuz (kideek horretarako baliabideak izatea, hauen nortasuna egiaztatzea...). Hausnarketa hau idazterako momentuan, COVID-19aren krisiaren ondorioz halabeharrez gure egunerokotasunean digitalizazioa izugarri bizkortu denean, erakunde eta entitate ezberdinetan teknologia berrien eta baliabide digitalen erabilpena erraztea eta bultzatzea helburu izan duten hainbat arau onartu izan dira, aztertzen gauden gaiari dagokionez 8/2020 Errege Dekretu-legea, martxoaren 17koa, COVID-19aren eragin ekonomiko eta sozialari aurre egiteko urgentziazko aparteko neurriak jasotzen dituena aipatu behar dugularik, bereziki bere 40 artikulua ${ }^{11}$, estatutuetan hala jasota egon ez arren Zuzenbide pribatuko pertsona juridikoen (kooperatibak barne) organoen bilerak bideokonferentzia edo aldibereko telefono bidezko konferentzia bidez egitea baimentzen duena, bertan jasota dauden baldintzak betetzekotan. Edozein kasutan, salbuespenezko arauketa baten aurrean egonda ${ }^{12}$, legedia arruntak kooperatiben estatutuek bilerak urrutitik egin ahal izateko aukera ere onartu beharko luke, esan bezala horretarako bermeak azpimarratuz.

Bestalde, batzarra hirugarren deialdian egiteko aukera, bilduta edo ordezkatuta dauden boto kopurua edozein izanda ere batzarra ospatzea posible izango delarik, irakaskuntza kooperatibei hedatzen zaie, aukera hau, beraz, aurrekoek eta kontsumo, nekazaritzako eta elikagaien kooperatibek erabil dezaketelarik (36.2 art.). Legeak bere zioen adierazpenean azaltzen duen bezala, neurri honek kooperatiba hauen errealitate soziologikoari eta parte-hartzearen logikari erantzuten die. Honek bazkideek batzar orokorrean parte hartzeko duten betebeharraren inguruan, legeak oraindik ere jasotzen duena (22.a art.), hausnartzeko beharra dakar. Parte hartzearen arazoa berria ez den arren, ikuspegi juridikotik behintzat betebehar hau legean mantentzeko beharra birplanteatzeko beharra dakar, eta batez ere ez-betetzearen ondorioak zeintzuk diren. Kooperatibaren barne diziplina-arauak garrantzia handikoak izan daitezke puntu honetan.

Azkenik, batzar orokorraren erabakiak aurkaratzeari dagokionez (41. art.) ere berrikuntza interesgarriak jaso ditu EKLak. Kooperatiben segurtasun juridikoaren izenean (eta hauen berezitasunak arriskuan jartzen

11 11/2020 Errege Lege-Dekretuak, martxoaren 31koak, aldatutakoa.

12 Gainera, gure ustez arauketa hau ez da Euskadiko kooperatibei aplikagarri (nahiz eta halako aukera erabili ahal izatea komenigarri izan daitekeen), hauen arauketa Autonomia Erkidegoaren eskumena den heinean. Zortzigarren Azken Xedapenak (eskumen-tituluari buruzkoak) ez du ere aspektu honen inguruko berariazko adierazpenik, merkataritza-legediaren aipamenaren kalterik gabe. 
ez direla ulertuta), legegileak gai honen arauketa KSLan jasotakora hurbiltzea erabaki du. Honela, esaterako, erabaki baliogabe edo deuseztagarrien arteko ezberdintasuna desagertu da, aurkaratze-akzioa egikaritzeko iraungitze-epea urte batera luzatu da kasu guztietarako (aurretik jasotako epea 40 egunetakoa zen deuseztagarriak ziren akordioetarako), eta aspektu ezberdinetan legeak KSLra igortzen gaitu, kooperatiben berezitasunak kontuan izatearen kalterik gabe (esaterako zaintza-batzordearen esku hartzeari dagokionez). Gainera, akordioa etetea eskatu ahal izateko bazkideek ordezkatu behar duten botoen kopurua ere txikitzen da (lehen \%20 edozein kasutan; portzentaje hau 10 bazkide baino gutxiagoko kooperatibetan mantentzen da, baina 10-50 bazkide artekoetan \%15era murrizten da, eta $\% 10$ era gainontzekoetan). Uler daiteke neurri honek bazkideen inplikazio faltaren arazoari nolabait erantzun nahi diola, orokorrean kooperatibaren tamainarekin batera handitzen dena, eta aldi berean bazkideen posizioa indartzea bilatzen duela. Honek, ordea, batzar orokorrerako eskaria egiteko beharrezko bazkide kopuruak mantentzearekin talka egin dezake.

\subsection{Administrazioa}

Administrazio-organoari dagokionez, berriro ere izaera-teknikoa duten aldaketak edo egokitzapen txikiak topa ditzakegun arren (esaterako, estatutuetan artezkaritza-kontseiluaren kideen kopurua zehaztuko dela jasotzen da, edo, gutxienez, horiek gutxieneko eta gehiengo kopurua, batzar orokorrak kasu bakoitzean zehaztu beharko duelarik - 43.1.II art.-; era berean, erabakiak hartzerakoan boto zuriak eta abstentzioak ez dira kontuan hartuko - 48 ter art.-), azpimarragarriagoak diren hainbat berrikuntza daude. Aurrekoa, mantentzen diren arauketaren aspektu batzuk ere azpimarragarriak izatearen kalterik gabe (hala nola, administrazio-organoak orokorrean artezkaritza-kontseiluaren forma hartuko duela, 10 bazkide arteko kooperatibetan administratzaile bakarra egotea mantentzen delarik; hau da, kooperatiba txikien kasuan izan ezik, EKLak ez du baimentzen kooperatiben administrazioorganoa administratzaile solidario edo mankomunatu batzuek osatzea).

Azpimarragarriak iruditzen zaizkigun aspektuen artean artezkaritzakontseiluan bazkideak ez diren kideei ezarritako muga malgutu izana dago (43.2 art.: kideen laurden batetik heren batera igotzen du muga), organoaren profesionalizazioa errazteko helburuarekin. Helburu berarekin, artezkaritza kontseiluaren idazkaria bazkidea eta kontseilaria ez izatea baimentzen da (47.2 art.; 4/1993 Legearen arabera, idazkariak kontseilaria izan behar zuen derrigor).

Era berean, bazkideentzako izendapena onartzea derrigorrezkoa dela gogorarazi beharra dago, salbu eta ez onartzeko bidezko arrazoia dagoe- 
nean, EKLak betebehar hori mantentzen duelarik (22.b art.). Azken honi lotuta, kontseilariek karguari uko egitearen kasua espresuki arautzen da, erabakia idatziz arrazoitu beharko dutelarik, artezkaritza kontseiluari dagokiolarik arrazoia justifikatuta dagoen ala ez, eta arrazoituta ez egotekotan administratzaileari kalte-galerak eskatzeko aukera dagoelarik (47.3 art. ${ }^{13}$ ).

Gainera, kooptazioa espresuki baimentzen da, hau da, artezkaritzakontseiluak berak behin-behineko izaerarekin postu gutxi batzuk hutsik geratzen badira eta ordezkorik ez badago ( 47.3 art.).

Horretaz gain, gorago aipatutakoaren harira, espresuki jaso da emakume eta gizonen arteko ordezkaritza orekatua kontuan hartzea estatutuetan xedatzeko aukera, artezkaritza-kontseiluaren osaerari dagokionez (47.6 art.). Esan bezala, holako aurreikuspenek berdintasuna lortzeko bidean lagundu badezakete ere, legea aspektu honekin zeinen malgua den deigarria da.

Batzar orokorraren kasuan bezala, artezkaritza kontseiluaren bilerak bideokonferentzia edo antzeko sistema bidez egiteko aukera aurreikusten da (48.1.II eta III art.), Euskadiko kooperatibei buruzko legedian berria ez dena, izan ere dagoeneko Euskadiko Kooperatiben Legearen Erregelamenduko 19 artikuluan jasota zegoen. Aspektu honi dagokionez, aurreko atalean egindako hausnarketak errepika ditzakegu.

Hala ere, administrazioaren erregimenaren aldaketa interesgarrienak arreta eta leialtasun betebeharrei buruzkoak dira, kapitalezko sozietateen legediari nolabaiteko hurbilketa ekarri dutelarik. Ordea, aldaketa hauek azpimarratu eta txalotu diren arren ${ }^{14}$, aipatutako hurbilketa oso mugatua dela esan beharra dago.

Positiboa den alderdietariko bat administratzaileen betebeharrak arautzeko artikulu konkretua jaso izana da (49 art.), 4/1993 Legean ez zelarik modu banatu eta espezifikoan arautzen (hauen erantzukizuna arautzerakoan egiten zitzaien aipamena arreta eta leialtasun betebeharrei, legearen

13 EKL 47.3 art.: Kontseilari batek bere karguari uko eginez gero, arrazoitu egin beharko du bere erabakia, idatziz, eta artezkaritza-kontseiluari jakinarazi; kontseiluak erabakiko du ea justifikatuta dagoen uko egiteko adierazitako arrazoia, eta idatziz jakinaraziko dio interesdunari.

Uko egitearen kalifikazioa batzar orokorrean edo errekurtso-batzordean errekurritu ahal izango $d a$, nahitaezko bajarentzat ezarritako baldintza eta epe beretan.

Kontseilari uko-egileak bere jakinarazpenean finkaturiko datan izango ditu ondorioak uko-egiteak; data hori ezin izango da izan jakinarazpena baino lehenagokoa.

Kooperatibaren ustetan uko-egitea ez badago arrazoituta, kalte-galerak ordaintzea eskatu ahal izango zaio, hala badagokio, dena delako administratzaileari.

${ }_{14}$ Aldaketa hauen inguruan, modu laburrean, Irastorza eta López (2020), neurriok txalotzen dituztelarik, kooperatiben benetako profesionalizazio eta modernizazio beharrei erantzuten dieten heinean, bereziki azken urteotan ikusitako zailtasunak kontuan izanda, aldi berean sozietate hauen oinarrizko balore eta printzipioei uko egiten ez zaielarik. 
testuan sakabanatuta zeuden betebehar hauen manifestazio ezberdinen kalterik gabe). Betebeharron edukiari dagokionez dauden berrikuntzak asko izan ez arren, eta oraindik ere gai honi buruzko arauen antolaketa guztiz egokia ez den arren (alde batetik, leialtasun betebeharraren edukiaren elementu batzuk artikulutik kanpo geratzen dira, eta beste alde batetik artikulu berean arreta eta leialtasun betebeharrak nolabait nahastuta agertzen dira - lehenengo eta behin arreta betebeharrari erreferentzia eginez, gero leialtasun betebeharrari, eta azkenik enpresa-diskrezionalitateari, arreta betebeharraren betepena baloratzeko elementua dena-), administratzaileen betebeharrei garrantzi handiagoa eman nahi izan zaiela nabaria da.

Aipatutako artikuluak betebeharron edukiaren inguruan jasotzen duenari so eginez, arreta betebeharraren zorroztasuna baloratzerako orduan kargua ordaindutakoa den ala ez kontuan izango dela, 4/1993 Legean aipatzen zena, ezabatu da. Horrela, EKLren arabera administratzaileek haien funtzio eta betebeharrak enpresaburu onaren arretaz bete beharko dituzte, kontuan harturik zer izaera duen haien karguak eta zer funtzio esleitu zaizkien, eta behar besteko neurri hartu beharko dituzte kooperatiba behar bezala kudeatzeko eta ordezkatzeko (49.1 art.). Era berean, arestian aipatu bezala, enpresa-diskrezionalitatearen babesari berariazko erreferentzia egiten zaio, KSL 226 artikuluaren ereduari jarraituz, kooperatiben berezitasunak kontuan izanda: Enpresa-diskrezionalitateari atxikitako erabaki estrategikoen eta negozio-erabakien arloan, ulertuko da enpresaburu onaren arretaren estandarra betetzen dela administratzailea onustez jardun denean, erabakiaren xede den gaian interes pertsonalik izan gabe, behar adina informaziorekin eta erabakitzeko prozedura egokiaren arabera jardunez. Ez dira enpresa-diskrezionalitatearen barruan jasoko kooperatibaren interesekiko gatazka eragiten duten edo eragin dezaketen erabakiak (49.5 art.).

Aldi berean, ordezkari leialei dagokien leialtasun betebeharra ezartzen $\mathrm{da}$, onustez eta kooperatibaren onurarako, eta esleitu zaizkien ahalmenak ezarritako helburuetarako baliatuko dituzte, eta ez beste ezertarako (49.2 art.); 4/1993 Legeak ordezkari leialari erreferentzia egiten zion bitartean, beraz, egungo legediak esleitutako ahalmenak ezarritako helburuak ez den beste ezertarako erabiltzea debekatzen du espresuki. Honi isilpeko datuak sekretupean gordetzeko beharra gehitzen zaio, haien funtzioak amaitu eta gero ere (49.3 art.), EKLren berrikuntza ez dena, 4/1993 Legean jasota baitzegoen. Artikulu beraren laugarren atalean araututako kooperatibari lehia ez egiteko edo honen interesekiko gatazka sortzen duten jarduerak gauzatzeko debekua ere ez da berez EKLren berrikuntza bat, 4/1993 Legearen 42.1.c eta 2 artikuluan egoera hau aipatzen baizen. Hala ere, azken honi dagokionez, EKLak hobekuntza nabarmenak jaso ditu, leialtasun betebeharraren beste eduki batzuekin batera arautuz (ez bakarrik administratzaile izateko debekuen artean), eta halako jarduerak gauzatzeko batzar orokorrak eman 
dezakeen baimena berariazkoa eta kasu berezietarako izango dela aurreikusiz, eta baimenik gabe egindako egintzak deuseztatzeko aukera jasoz, salbu hirugarren ez-bazkide onustedunek eskuraturiko eskubideen kasuan. Horrez gain, holako egoera batean inplikatutako administratzaileak horren berri emateko betebeharra ezartzen da, ezingo duelarik bozketan parte hartu.

Ordea, EKLk ez ditu arreta eta leialtasun betebeharren eduki diren bestelako betebeharrak jasotzen eta arautzen, hala nola dedikazio egokia izatea, kooperatibaren informazioa eta egoera ezagutzeko eskubide eta betebeharra edo, batez ere, auto-kontratazioaren erregimena, edo administratzaileen eta, bere kasuan, honi lotutako pertsonen bestelako interes-gatazkak. Egia da hauek interes gatazkak sortzen dituzten jardueren debeku orokorrean barneratuta daudela uler daitekeela baina, gure ustez, posible eta egokia litzateke betebehar hauen legezko garapen handiagoa eta argiagoa (bereziki auto-kontratazioaren eta lotutako pertsonen kasuan), gai garrantzitsu hauen inguruko araubidea argituz, eta aldi berean kooperatiben legediari gehiegizko konplexutasuna ekidinez, honen barruan oreka bat lortuz eta, batez ere, entitate hauen berezitasunak errespetatuz. Zentzu honetan, arestian esan bezala, betebeharron arauketa EKLren aldaketa handietarikoa dela aipatu den arren, hauen edukiari dagokionez errealitatean ez da aldaketa oso handirik ere atzematen, beste lege batzue$\tan \left(\right.$ ez bakarrik KSLan ${ }^{15}$, baita ere kooperatibei buruzko legeetan ${ }^{16}$ ) aspektu hauek aurretik ere garatuago daudelarik. Edozein kasutan, arreta eta leialtasun betebeharrak administratzaileen oinarrizko betebeharrak direla gogorarazi behar da, legeak hauek jaso eta garatu zein ez bete beharrekoak direnak ${ }^{17}$.

Betebeharron arauketa 50 eta 51 artikuluekin osatzen da, administratzaileen erantzukizunaren eta egikaritu daitezkeen akzioen ingurukoak. EKLaren berrikuntza aipagarrienetarikoa erantzukizun hau berariaz egitezko administratzaileei hedatzea da (hala administratzaile izendatu gabe haren funtzioak betetzen dituena nola sozietateko administratzaileek beren jardunerako jarraitzen dituzten jarraibideak ematen dituena), kontrakoa frogatu ezean kooperatibari laguntza finantzarioa baldintza eta errekerimendu batzuk ezarrita eskaintzen dion hartzekoduna kontzeptu honen barruan sartzen ez delarik (50.4 art.). Azken argipen honek garrantzia berezia izan lezake kooperatiben arteko lankidetza eta laguntza sareei dagokienez. Era berean, izaera teknikoa duten bestelako hobekuntzez gain, leialtasun betebeharra urratuz modu bidegabean lortutako aberastasuna bueltatzeko be-

15 Ikusi KSL 225-231 art.

16 Esaterako, autokontratazioaren araubidearen inguruan, lotutako pertsonekin egindako operazioak barne Estatuko Kooperatiben Legea (27/1999 Legea, uztailaren 16koa; 42 art.).

17 Honen guztiaren inguruan, ikusi Grimaldos (2013) edo Villafáñez (2016). 
tebeharra jasotzen da, sozietatearen ondareari egindako kaltea ordaintzeko betebeharraz gain (51.7 art.).

Kargua ordaintzeko aukera ere garatu da (45 art.), neurri batean kapitalezko sozietateen legedia oinarri bezala hartuz. Kargua printzipioz dohainezkoa izango den arren (karguaren ondoriozko gastuak ordaintzearen kalterik gabe), ordainduzkoa ere izan daiteke, aukera hau estatutuek berariaz onartzen badute ordainsariak zehazteko irizpideekin batera, batzar orokorrari dagokiolarik urtean zenbat ordaindu behar den zehaztea (4/1993 Legeak estatutuek edo batzar orokorrak kontseilariei ordainsariak esleitzeko aukera jasotzen zuen, besterik zehaztu gabe). Gainera ordainsariak kooperatibaren garrantziarekin, unean uneko egoera ekonomikoarekin eta, batez ere, administratzaileek beren karguan dihardutenean emandako benetako prestazioekin proportzioa gorde beharko duela gehitzen da. Beraz, ordainsariei dagokienez irizpide argiak izatea, proportzionaltasuna eta gardentasuna indartu nahi izan dira; honen isla da ere aurreko guztia urteko memorian jasotzeko beharra ${ }^{18}$.

\section{Araubide ekonomikoa. Bereziki, bazkideen erantzukizuna eta galerak egoztea}

Kooperatiben kapitalari egindako ekarpenen araubideari eta bestelako finantzaketa-instrumentuei dagokionez ez dago aldaketa nabarmenik EKLan, 60.1.b artikuluko ekarpenen (batzar orokorrak edo artezkaritza-kontseiluak baldintza gabe ukatuz gero itzultzeko eskubiderik ez duten ekarpenak) inguruan egiten diren zehaztapen berrien kalterik gabe (esaterako, ekarpen-mota aldatzen denean estatutuak aldatzeko beharra), edo bestelako aldaketa txikien kalterik gabe (hala nola, sozietatearen kapitala murriztea erabakitzen denean edo jarduera kooperatibizatua murrizteagatik ekarpenak bueltatzeko aukera, 66.6 artikuluaren arabera, aldez aurretik Euskadiko Kooperatiben Legearen Erregelamenduan jasota zegoena).

Puntu honetan aipagarria da 60.6.VI artikuluan jasotako mendeko finantzaketei dagokienez egindako zehaztapena: Eskaintza-jaulkipena baimentzeko eskumena duten agintaritza ekonomikoek informazioa gain-begiratu eta onartu ondoren, organo gainbegiratzaile eskudunak ezarritako entitate arduradunak arduratuko dira informazio hori hirugarren ez-bazkideek jaso dutela bermatzeaz. Aurrekoak finantzaketa instrumentu hauen komertzializazioarekin egondako arazoei erantzun bat eman nahi izan die,

18 Kooperatiben administratzaileen ordainsariaren inguruan (arreta betebeharraren balorazioan kargua ordaindukoa den ala ez kontuan izateari dagokionez ere), García Álvarez (2015). 
izan ere, legezko instrumentuak izan arren arrisku handiko finantzaketa instrumentu konplexuak direla gogorarazi behar da. Hori dela eta, epai ezberdinek finantzaketa hauek eskuratu zituzten hainbat pertsonaren erreklamazioak onartu izan dituzte, bereziki kontsumitzaileen kasuan, kontratuan behar bezalako adostasuna egon ez dela ulertuta ${ }^{19}$. Zentzu honetan, aipatutako artikulua bera baino argigarriagoa izan daiteke legearen zioen azalpena: Produktu finantzarioetan inbertitzen duten inbertitzaile eta kontsumitzaileak babesteko ordenamendu juridikoan hainbat arauren bidez garatutako espirituari jarraikiz, batez ere, finantza-sektoreko arauei, lege honetan gogora ekartzen da nahitaezkoa dela inbertitzaile eta kontsumitzaile horiei informazio egokia, argia eta ulergarria ematea. Era berean, gogorarazten da indarrean dauden betekizunak bete beharko direla lege honetan erregulatutako mendeko ekarpen finantzarioak harpidetzeko, eta emandako informazioa nahikoa, argia eta ulergarria izan dadin bermatu behar dela. Inbertsio-zerbitzuak ematen dituzten entitateek nahitaez bete beharko dute informazio-betebehar hori, aipaturiko tresna finantzarioak eskuratu nahi dituzten kontsumitzaileei informazio gardena eta zuzena emateko errekerimenduak betez.

Bestalde, soberakinak banatzeari dagokionez ere ez dago aldaketa aipagarririk, orokorrean Nahitaezko Erreserba Funtsaren (NEF) eta Kooperatiba-Heziketa eta Sustapenerako eta Interes Publikoko beste Helburu Batzuetarako Ekarpenaren (gaztelerazko COFIP laburdurarekin ezagutu ohi dena) arauketa mantentzen delarik. Azken honi dagokionez, 6/2008 Legearen, ekainaren 25ekoa, aldaketak mantentzen dira, horrek bere izaera argitu zuelarik (ez da berez kooperatibaren funts bat, baizik eta legeak baimendutako helburu bati edo batzuei zuzendu beharreko ekarpena, hau enbargatzeko debekua ere hobeto azaltzen duena; ekarpenaren izena ere bere izaerari egokitu zitzaion, aurretik Kooperatiba-Heziketa eta Sustapenerako Funtsa izena baitzuen ${ }^{20}$ ) eta bere helburu posibleak zabaltzen zirelarik. EKLak helburuon artean gehitzen du bazkideei eta langileei formakuntza eta heziketa ematea, kooperatibetan emakumeen eta gizonen berdintasuneranzko urratsak egiteko politika eraginkor bat sustatze aldera $(72.1 \text {.f art. })^{21}$.

19 Ikusi Martínez Balmaseda (2015, 297-306 orr.). Esaterako, Bilboko 1 Merkataritza Epaitegiaren 20/2014 epaia, urtarrilaren 27koa.

20 Estatuko gainontzeko kooperatibei buruzko legedian hori mantentzen delarik.

21 COVID-19aren ondoriozko eragin ekonomikoei aurre egiteko, 15/2020 Errege Dekretu-Legeak, apirilaren 21ekoak, ekonomia eta enplegua laguntzeko urgentziazko neurri osagarriak jasotzen dituenak, 13 artikuluan modu tenporalean Kooperatiba-Heziketa eta Sustapenerako Funtsa erabiltzeko arauak malgutu ditu. Berriro ere, kontuan izan Estatu-mailako arau bat dela. Salbuespenezko arauketa honen arabera, Funts hau, baldintza batzuekin, kooperatibari likidezia emateko erabil liteke, eta baita COVID-19aren osasun-krisiari eta bere efektuei aurre egiteko egintzetarako, Artezkaritza Kontseiluak honen inguruko erabakiak har ditzakeelarik. 
Zalantzarik gabe, kooperatiben arauketaren inguruan gai gatazkatsuenen artean bazkideen erantzukizuna eta hauei galerak egozteko aukera dago. Gai hau jorratzeko abiapuntua da kooperatiben bazkideek sozietatearen zorren gain duten erantzukizun ${ }^{22}$ mugatua edo mugagabea ez dela sozietate hauen ezaugarri tipologikoa, legegileak aukera ezberdinak dituelarik arlo honetan. Doktrinaren zati batek azaltzen duen bezala, ordea, bazkideek sozietatearen zorrengatiko erantzukizuna (kanpo-zorrengatiko erantzukizuna) mugatua izan arren, egotzitako zorrengatiko erantzukizuna (barne-zorrengatiko erantzukizuna) mugagabea izan liteke. Horretarako kontuan izan den elementuetariko bat galeren eta jarduera kooperatibizatuaren arteko harreman posiblea da, jarduera kooperatibizatuaren ondorioz sortu litezkeen galerak errealitatean bazkideen galerak direla ulertuta ${ }^{23}$.

Euskadiko kooperatibei buruzko legediari dagokionez, 4/1993 Legeak dagoeneko bazkideen erantzukizun mugatua aurreikusten zuen, baita ere baja kasuan, zioen azalpenean aginduko araua zela azpimarratuz ${ }^{24}$. Hala ere, galerak bazkideei egozteko aukerak muga horren benetako norainokoa ezbaian jartzen zen, doktrinak iritzi ezberdinak plazaratzen zituelarik. Oraingoan eztabaida honetan sakontzeko asmorik gabe, EKLaren edukia eta legedian egindako aldaketa edo argipenak hobeto ulertzeko gakoak azpimarratuko ditugu. Zentzu honetan, doktrinaren zati baten arabera, galerak bazkideei egozteko araubidea bazkideen erantzukizun mugatuarekin batera interpretatu behar da, lehenengoak kapitalari egotzi ahal zaizkion galerak izanda, beti ere kooperatiben araubide ekonomikoaren berezitasunak kontuan izanda. Hau da, kooperatiben legeak errealitatean kapitalari egozgarri zaizkion galerak egozteko sistema berezia jasotzen du, sozietateon berezitasunekin bat datorrena (modu nabarmenean, bazkideek sozietatearen emaitzetan jarduera kooperatibizatuaren arabera parte hartzea, eta ez kapitalean duten partaidetzaren arabera), baina ez sozietatearen ondasun eta eskubideekin estali ezin daitezkeen galerak azken aukera bezala bazkideei egozteko beharra, hauek haiek ondare pertsonalarekin estaltzeko ${ }^{25}$. Honek, noski, ez du esan nahi kooperatiben bazkideek sozieta-

${ }^{22}$ Lan honetan «erantzukizun» hitza erabiltzen dugu, hau baita legean eta doktrinan jaso ohi dena. Hala ere, komenigarria da gogoraraztea zehatzagoa dela bazkideek beren gain hartzen duten arriskuari buruz hitz egitea.

23 Irizpide hau jarraituz, esaterako Balentziako Kooperatiben Legeak (2/2015 Dekretu Legegilea, maiatzaren 15ekoa; 69 art.) bazkideei jarduera kooperatibizatuaren ondoriozko galerak egoztea aurreikusten du (ez gainontzeko galerak). Ideia bera topa dezakegu Madrileko Kooperatiben Legean (4/1999 Legea, martxoaren 30ekoa; 61 art.).

24 1982eko Euskadiko Kooperatiben Legearen arabera estatutuetan posible zen bestelako erantzukizun erregimena jasotzea.

25 Gaiaren inguruan doktrinak dituen iritzi ezberdinen inguruan, eta 4/1993 Legeari dagokionez, ikusi Martínez Balmaseda (2014, 289-296 orr.). Bereziki, azaldutako interpretazioa eta 
tearekin egindako jardueren baldintzek ez dutela azterketa juridikorik (eta bere kasuan ondoriorik) merezi, ezta ezin dutenik bestelako erantzukizunik izan, kooperatibaren konkurtsoaren kasuan masa aktiboari kaltegarriak diren egintzei buruzko araubidea aplikatu litekeelarik ${ }^{26}$, eta, bere kasuan, sozietatearen azpi-kapitalizazioagatiko erantzukizun posiblea ere planteatu litekeelarik ${ }^{27}$.

2013an Fagor Electrodomésticos kooperatibaren konkurtsoak gai honen inguruko interpretazio zalantzak berriro ere mahai gainean jarri zituen, honen bazkideek entitateak zegoeneko pilatuta zituen milioitako galerengatik erantzukizuna izan zezaketelakoan, azkenean horrela izan ez zelarik. Egoera honen aurrean EKLak, gai honen arauketan funtsezko aldaketarik egiten ez duen arren, bazkideen erantzukizunaren eta galerak egoztearen araubidea gehiago argitzeko saiakera egin du, aurreko paragrafoan azaldutako interpretazioaren alde modu are argiagoan alde eginez. Honela, 59 artikuluaren idazkera berrian kooperatibaren erantzukizun unibertsalari erreferentzia egiten zaio, honek, pertsona juridiko independentea denez, bere ondare propioa duela azpimarratuz, sozietatearen zorrengatik ondare horrek erantzun beharko duelarik (COFIParen zenbatekoa alde batera utzita). Era berean, bazkideen erantzukizuna mugatua dela mantentzen da, baita baja kasuan ere (hala ere, hurrengoa gehitzen da: Baina, bazkideek, baja eman eta gero ere, erantzukizuna izango dute baldin eta kontratuak izenpetu edo betebeharrak hartu badituzte, berariaz eta espresuki, sozietate kooperatiboarekin, eta betebehar horiek ez badira azkentzen, beren izaera dela-eta, bazkide izateari utzi eta gero).

Bestalde, galerak egozteari dagokionez (73 art.), oinarrizko arauketa mantentzen da, egokitzapen batzuekin (esaterako, epeei dagokienez), NEFren erabilera malgutuz (kapitalaren $\% 50$ gainditzen duenean portzentaje horretatik gorako zenbatekoa galerak konpentsatzeko erabiltzea baimentzen da), eta galerak bazkideei egoztea hauen erantzukizun mugatuaren kalterik gabe izango dela azpimarratuz. Honela, legeak ezarritako epeak igarotzean oraindik ere konpentsatu gabeko galerak badaude, ba-

bazkideei galerak egozteko sistemak ezin duela hauen erantzukizun mugatua hutsaldu defendatuz, beste batzuen artean (Euskadiko legediaren azterketa berezia eginez ere, beste legeen azterketaren kalterik gabe): Gadea (2012, 275-277 orr.) edo Villafáńez (2014, 241-292 orr.).

Bazkideen erantzukizunaren araubidea ere aztertuz, bestelako interpretazio bat eginez (bereziki Estatuko Kooperatiben Legea aztertuz), besteak beste, Viteri (2016).

${ }^{26}$ Lan hau idazterako orduan Lege Konkurtsalaren 71-73 artikuluetan (22/2003 Legea, uztailaren 9koa; 2020ko irailaren 1ean 1/2020 Errege Dekretu Legegileak, maiatzaren 5ekoak, Lege Konkurtsalaren testu bateratua onartzen duenak, ordezkatuko duelarik: 226-238 art.).

27 Gadea (2012, 276 orr.), Villafáńez (2014, 265 eta 281-292 orr.), Suso (2013, 15701571 orr.). 
tzar orokorrak erabakitako ekarpen berriekin edo bazkide izaten jarraitzeko egin beharreko ekarpen berriekin kitatu beharko dira. Bazkidearen ekarpenak estatutuetan ezarritako gutxiengora heltzen ez badira eta ekarpen berririk egiten ez badu, baja emango zaio (71.4 art.). Azken zehaztapen hau 61.3 artikuluan jasotakoarekin bat dator (4/1993 Legean ere jasotzen zena), bazkideari kooperatibaren galerak egoztearen ondorioz bere ekarpena estatutuek edo batzar orokorrak zehaztutako gutxieneko zenbatekora heltzen ez denean bazkide izaten jarraitzeko ekarpen osagarri bat egin beharko duela agintzen duenean. Ildo beretik, EKLak baja ematen duen bazkidearen kasuan zenbatu beharreko galerek sozietatearen kapitalari egindako ekarpen osoaren muga izango dutela argitzen du (66.3 art.).

Azkenik, EKLak kontabilitateari eta sozietatearen dokumentaziori dagozkion aldaketa batzuk ere jasotzen ditu (75. eta 76. art.), hala nola urteko kontuak ekitaldia ixten denetik gehienez ere 3 hilabetetan egiteko beharra, erregelamendu bidez ezarritako mugak gainditzean kanpo-auditoretza egiteko beharra, edota bazkideen gutxiengo batek kanpo-auditoretza eskatzean honen gastuak hauek ordaintzeko beharra (kontabilitatean funtsezko akatsik edo irregularitaterik antzematen bada zenbatekoak itzultzearen kalterik gabe).

\section{Estatutuen eta egiturazko aldaketak}

Estatutuen aldaketaren araubidea aldatzen ez den bitartean, egiturazko aldaketei dagokienez berrikuntza interesgarriak daude, 4/1993 Legean aurreikusten ez ziren egiturazko aldaketak baimentzen direlarik ${ }^{28}$.

Alde batetik bat-egite berezien esparrua zabaltzen da (87. art.). 4/1993 Legean lan elkartuko kooperatiben eta sozietate anonimo laboralen bategitea eta nekazaritzako kooperatiben eta eraldaketako nekazaritza-sozietateen bat-egitea bakarrik baimentzen zen bitartean, kooperatiba izan behar zelarik beste sozietatea bereganatzen zuena edo sortzen zen sozietate berria, EKLak aurreikusten dituen aukerak anitzagoak dira. Honela, arauketa berriaren arabera, kooperatibek (mota zehaztu gabe) bat egin ahal izango dute sozietate zibilekin, merkataritza-sozietateekin edo bestelako entitateekin, kooperatiba izan daitekeelarik beste entitateak bereganatzen dituena, sortzen den sozietate berria edo beste entitate batek bereganatutakoa. Ildo beretik, kooperatiba ez den entitatearen alde ere kooperatiba zatitzea baimentzen da (88 art.). Bi kasuotan, bat-egite batean kooperatiba beregana-

28 Irastorza eta Lópezek (2020) ongi etorria ematen diete aldaketoi, zailtasun handiak dituzten kooperatibei enpresa desagertzea ez den alternatibak ematen baitizkiete. 
tutako sozietatea denean eta kooperatiba ez den entitatearen alde zatitzea dagoenean, NEFak, COFIPak eta banaezinak diren bestelako funtsek eraldaketa kasuetarako azpian azaldutako trataera izango dute.

Transformazioari dagokionez, bere arauketa oinarrian mantentzen den arren (89 eta 90 art.), eragin ezberdina duten aldaketak jasotzen dira (esaterako, zaintza-batzordearen parte hartzeari dagokionez), kooperatibaren funtsei dagozkienak azpimarratuko ditugularik (89.5 art.). NEFaren eta estatutuen eta batzar orokorraren erabakiaren arabera izaera banaezina duten borondatezko erreserba funtsen kasuan EKGKren esku jarriko dira, konpentsatu beharreko galerak edo balantzean aktiboek izandako minusbalioa kontuan izanda (salbu aplikazio edo helmuga zehatz bat ezarri zaizkien borondatezko funtsak). COFIPak estatutuetan aurreikusitako xedeetarako erabiliko da eta, halakorik ezean, likidazio-kasuetarako ezartzen den xederako.

\section{Desegitea eta likidatzea}

Atal honetan kooperatibaren konkurtsoari, likidatzaileen inguruabarrei eta likidazio kasuan sozietatearen ondasunak adjudikatzeko arauei erreferentzia egingo diegu, EKLari dagokienez interes handiena dutelakoan.

Konkurtsoari dagokionez, aldez aurretik indarrean zegoen arauketa mantentzen da, terminologia Lege Konkurtsalari egokituz. Honi dagokionez bereziki deigarria deritzogu 92.5.III artikuluari, Konkurtso-prozeduren kasuan, eta likidazio-fasea hasi bada (4/1993 Legeak "porrot kasuan" esaten zuen), hitzarmen bat sinatu behar da hartzekodunekin kooperatiba berriro jartzeko jardunean esaten duenean. Aurreikuspen hau harrigarria da konkurtsoari buruzko legedian hitzarmena eta likidazioa alternatiboak direnean bata bestearekiko, likidazioa zuzenean irekiko delarik zordunak hala eskatzen duenean edo hitzarmen-fasearen porrotaren ostean, behin likidazioa hasita hitzarmen bat tramitatzea ez delarik aurreikusten. Likidazioan dagoen konkurtsatua berriro ere berraktibatzeko aukera bera ere oso zalantzagarria da, eta kasuren batean aukera hau planteatu den arren, ordaintzeke zeuden kreditu guztiak ordaindu diren kasurako izan da (hortaz, kaudimen-gabezia desagertzeagatik konkurtsoa bukatu denerako) ${ }^{29}$. Horregatik, konkurtso baten ondoriozko likidazioan dagoen kooperatiba berriro ere jardunean jartzeko aukera kooperatiba legean ez jasotzea egokiagoa litzateke, konkurtsoari buruzko legediarekin talka egiten duen heinean.

\footnotetext{
29 Fernández Abella (2018).
} 
Bestalde, likidazioari dagokionez EKLren berrikuntza azpimarragarrienetarikoa bazkideak ez diren likidatzaileak izendatzeko aukera da. $94.1 \mathrm{ar}-$ tikuluaren arabera batzar orokorrak ahal bada bazkideen artetik aukeratuko ditu likidatzaile bat edo gehiago, beti kopuru bakoitietan, hauek kooperatibako bazkide ez diren pertsona fisiko edo juridikoen artean izendatuko direlarik bidezko arrazoia adieraziz bazkideetako inork ez badu nahi likidatzaile izan. Era berean, likidatzaileak hainbat direnean, batzar orokorrari dagokio aplikatuko den araubidea erabakitzea (96.1 art.; 4/1993 Legearen arabera likidatzaileek modu kolegiatuan lan egin behar zuten, gaur egun, beraz, modu solidarioan edo mankomunatuan ere funtzionatu dezaketelarik). Legearen zioen azalpenen arabera, xedapenon helburua sozietatearen likidatzea eta azkentzea modu ordenatuan egitea bermatu nahi da, kooperatibak erabat desegituratuta badaude, bazkiderik ez badago, bazkideak ezgaitzat hartzen badira edo bazkideek likidatzaile izateari uko egiten badiote. Aukera hau jasotzea positiboa izan daitekeen arren, bere arauketa eskasa azpimarratu behar da, zioen azalpenean eta 94.1 artikuluan jasotako edukia ez datozelarik guztiz bat (nahiz eta lehenengoak, hala ere, azken hau eta bidezko arrazoia zer den interpretatzeko lagundu dezakeen), eta bidezko arrazoiaren balorazioaren inguruabarrak ez direlarik argitzen.

Azkenik, kooperatibaren ondasunak adjudikatzeko araubideari dagokionez (98 art.), hauen aldaketa eza aipatu behar dugu, gure ustez bere idazketa hobetzeko eta argitzeko aukera galdu delarik. EKLren arabera, 4/1993 Legearen idazketa mantenduz, Sozietatearen ondasunak ezin izango dira ez adjudikatu ez banatu sozietatearen zorrak erabat kitatu arte, zorrok kontsignatu arte edo muga-egunera iritsi ez diren kredituak ordainduko direla ziurtatu arte. Zor horiek kitatu ondoren, hurrenkera honetan adjudikatuko dira sozietatearen gainerako ondasunak: a) COFIPa EKGKren esku jarriko da (...). Artikulu honen idazkerak likidazio kasuan COFIParen zenbatekoa kooperatibaren zorrak ordaintzeko erabil litekeela ulertarazi dezake. Hala ere, COFIParen izaera, helburua eta enbargatzeko ezintasuna kontuan izanda, kasu honetan ere bere zenbatekoa bere helburuak betetzeko betebeharrak ordaintzeko erabili beharko da, soberakina zuzenean EKGEren esku jarrita ${ }^{30}$.

\section{Kooperatiba motak}

Legeak kooperatiba mota desberdinak erregulatzen ditu eta, gainera, legearen zerrendan agertzen ez diren kooperatiba motak sortzeko aukera

${ }^{30}$ Gadea (2012, 274-275 orr.) eta Villafáńez (2014, 231-234 orr.). 
ematen du, kooperatibizatutako jarduera sozioekonomikoaren arabera. Kasu horretan, antza gehien duen kooperatiba motaren legedia aplikatuko da (102.1 art.).

Kooperatiba mota bakoitzari bere araudi berezia aplikatuko zaio lehentasunez eta, araudi horretan aurreikusi gabeko gaietan, ordezko moduan kooperatiben araudi komuna aplikatuko da $(102.3 \mathrm{art} .)^{31}$.

Zalantzarik gabe, Euskal Herrian, kooperatiba mota nagusia lan elkartukoa $\mathrm{da}^{32}$. Kooperatiba mota hau sortzen da pertsona talde bat elkartzen denean beren buruari enplegu kooperatiboa emateko, edozein jarduera ekonomiko edo profesional eginez, bazkideak ez diren hirugarren pertsonentzat ondasun edo zerbitzuak elkarrekin ekoitziz (103.1 art.).

EKLak espresuki azpimarratzen du, bere aurrekoak egiten zuen bezalaxe, bazkideak beren kooperatibarekin lotzen dituena sozietate-harremana dela, eta ez lan-harremana (103.1 art.).

Bazkideen lan baldintzak zehazteko, autoeraketaren sistema mantentzen da. Legeak galdaturiko salbuespen bakarra da lan-aurrerakinaren (soldatapekoen soldataren baliokidea) zenbatekoa, gutxienez, lanbidearteko gutxieneko soldataren parekoa izan beharko dela. Gai honetan, berrikuntza garrantzitsu gisa, legeak dio edonola ere, kooperatibak berak zehaztutako lan-erregimenak, lan-baldintza duinak eta Lanaren Nazioarteko Erakundeak zehaztutako gutxieneko lan-estandarrak errespetatuko ditu (105.3 art.). Aurreikuspen txalogarri honek, lan duina bermatuz, kooperatiba faltsuetan gertatzen den esplotazio laboralaren aurkako borrokan lagundu dezake.

Beste kooperatiba motek bazkide ez diren hirugarrenekin harreman ekonomikoak eduki dezaketen modu berean, lana, lan elkartuko kooperatibetan kooperatibizatutako jarduera izanik, bazkide ez diren soldatapekoek ere egin dezakete. Lehen, bazkide ez diren soldatapekoak kontratatzeko gehienezko muga bazkide langileek egindako lanorduen \%25ean zegoen. Lege berriak muga hori \%30a arte igo du.

Legeak espresuki ondokoa dio: Lan elkartuko kooperatiben helburua da bazkideei enplegu bat ematea eta haiek lan egitea (103.4 art.). Beraz, bazkideak ez direnen lana salbuespena izan beharko litzateke, eta lan horren gehienezko muga igotzea enplegu kooperatiboaren kontrako norabidean doa. Eta hori, zioen azalpenean esaten denez, arrazoi operatiboak direla eta. Aldaketa hau ez zaigu justifikatuta iruditzen.

31 EKLak zerrendatzen dituen kooperatiba motak, jardueraren arabera, ondokoak dira: lan elkartua; kontsumoa; irakaskuntza; nekazaritza eta elikagaiak; erkidegoan ustiatzea; etxebizitza; finantzak; osasuna; zerbitzuak; junior; gizarteratzea; eta enpresak sustatzea.

32 Lan elkartuko kooperatibetan egiten den lanaren gaian sakontzeko, bai kooperatibistek eta bai soldatapekoek egiten dutena, Bengoetxea (2019), De Nieves (2005) eta López (2006). 
Gainera, \%30eko muga hori gainditu ahal izateko salbuespenen zerrenda handitu egin da. Arrazoi batzuk 4/1993 legean ere agertzen ziren, besteak beste, soldatapekoak espresuki bazkide langile izateari uko egitea, edo soldatapekoak kooperatiban legezko subrogazioaren ondorioz sartzea. Gehitu diren kasu berrien artean, aipatu ditzakegu desgaitasuna duten soldatapekoak, formaziorako kontratuak eta kontratuak praktiketan, edo enpresa erabiltzaileei lagaturiko soldatapekoak, kooperatiba aldi baterako laneko enpresa denean.

Irakaskuntza kooperatibek (109-111 art.) garrantzi kuantitatibo eta kualitatibo nabarmena dute Euskal Herrian, batez ere ikastolen gizarte mugimenduagatik, kooperatiba forma duten ikastetxeak izanik.

Legeak hiru irakaskuntza kooperatiba mota aurreikusten ditu: kontsumo kooperatibak, kooperatibizatutako jarduera Irakaskuntza zerbitzuaren erabiltzaileena denean (gurasoak, ikasleak); lan elkartuko kooperatibak, kooperatibistak irakasleak eta irakasle ez diren langileak direnean; eta kooperatiba integrala, kooperatibistak direnean aipaturiko bi kolektiboak, hots, irakaskuntza zerbitzua eskaintzen dutenak, eta jasotzen dutenak.

Lege berriak etxebizitza kooperatibak indartzen ditu (117-122 art.). Araubide juridiko berezia dute kooperatiba hauek, babes ofizialeko etxebizitzetaz eta kooperatiboa ez den sustapen pribatuko ereduaz aldentzen dena.

Jardunbide desegokiak izan diren hainbat esperientzien ondorioz, legearen asmoa da benetan kooperatibistek gidatzea etxebizitzen eraikuntza eta kudeaketa, kontuan hartuta, sarritan, ez direla ezagutzen elkarren artean. Horregatik, legeak ondokoa dio: Nolanahi ere, kooperatibak berak garatu beharko du, zuzenean, helburu soziala, gutxienez oinarrizko alderdietan. Hala eta guztiz ere, kooperatibak hirugarren ez-bazkideak kontratatu ahal izango ditu helburua lortzeko edo osatzeko. Kontratu horiek kooperatibaren legelari aholkulariaren aldeko irizpena jaso beharko dute (117.1 art.).

Kooperatibaz kanpoko entitate kudeatzaile bat egon daitekeen arren, kooperatibaren aholkulari gisa, legeak nahi duena da betiere kooperatibak gidatzea etxebizitzen sustapenaren prozesua. Horregatik, kooperatibek mota horretako aholkulariekin egin ditzaketen kontratuak baita ere aholkularia den letratu batek baimendu beharko ditu. Azken honen jardueraren zentzua etxebizitza kooperatibaren protagonismoa indartzea da. Oro har, letratu aholkulari horren irizpena eskatzen da kooperatibak egin nahi dituen operazio juridiko-ekonomiko nagusien inguruan. Hirugarrenekin egiten diren jarduerek zuzenbide kooperatiboan ohikoa den muga dute, \% 30ekoa.

Azpimarratu nahi dugu lege berriak etxebizitzen erabilera lagatzeko kooperatibaren figura indartzen duela. Kooperatiba etxebizitzen jabea da, eta beren erabilera lagatzen die kooperatibistei. Aukera hau etxebizitza librearen alokairuaren antzekoa da, ohikoa den etxebizitzen jabetza esleipe- 
naren formularen alternatiba gisa. Oro har, lagatzearen aukeraren erabilera handitzen ari da, eta zuzenbide konparatuan indarra hartzen ari da.

Garraio kooperatibei dagokienez (129 art.), praktikan egon diren erabilera okerrak ekidin, eta araubide juridikoak argitzeko, bi mota desberdintzen dira. Garraio kooperatibak lan elkartuko kooperatibak izan daitezke, garraiolarien lana kooperatibizatzen denean; edo zerbitzu kooperatibak izan daitezke, kooperatibak bere bazkide kooperatibistak diren garraio enpresa desberdinei zerbitzuak eskaintzen dizkienean.

Legeak kooperatiba mota berri bat ekarri du, junior kooperatiba (132 art.). Ondasun eta zerbitzuak ekoizteko kooperatiba da, lan elkartuko kooperatiben moduan, baina junior kooperatibak ikasleek sustaturikoak dira, beren formazio akademikorako tresna gisa, hezkuntza sistemaren baitan.

Horregatik, junior kooperatibak aldi baterakoak dira, hezkuntza zikloarekin bat eginez. Kooperatiba hauek beren jarduera ikasle sustatzaileen titulazio akademikoaz haratago luzatuz gero, lan elkartuko kooperatiba arruntetan bihurtuko dira.

Gizarteratze kooperatibak (133 eta 134 art.), lehen bakarrik desgaitasuna duten langileentzat aurreikusten ziren, eta EKLrekin gizarte bazterketa egoeran dauden pertsonetara zabaltzen dira. Koherentea eta txalogarria da aukera kooperatiboa eskaintzea babesturiko enpleguaren aukera duten bi kolektiboei: enplegu zentru bereziak, desgaitasuna duten pertsonentzat; eta gizarteratze enpresak, gizarte bazterketa egoeran daudenentzat.

Azkenik, enpresak sustatzeko kooperatiben mota berria aipatu nahi dugu (135 art.), tresna kooperatibo gisa ekintzailetza egitasmoa duten pertsonentzat, babesa eskainiz orientazioan, formazioan, eta tutoretzan.

\section{Sozietate kooperatibo txikia}

EKL baino lehen, sozietate kooperatibo txikia lege berezi batean zegoen erregulatuta, eta orain lege orokor berriak bere baitan sartu du (136145 art.), edukian ia ezer aldatu gabe. Teknika legegile egokia dela iruditzen zaigu EKLak egin duena.

Kooperatiba txikia lan elkartukoa edo erkidegoan ustiatzekoa izan daiteke. Gutxienez bi eta gehienez hamar bazkide langile (lan elkartuko kooperatibetan), edo lan-bazkide (erkidegoan ustiatzeko kooperatibetan) eduki ditzake. Betiere, bazkide langile edo lan-bazkide horiek kooperatibarekin duten harremana iraupen mugagabekoa izan behar da.

Kooperatiba txikiek, sortu osteko lehen bost urteetan, soldatapekoak eta iraupen mugatuko bazkideak kontrata ditzakete, baina horien zenbatekoak ezin du gainditu iraupen mugagabeko bazkideen kopurua. Bost urteak igaro ondoren, soldatapekoak kontratatzeko mugak EKLan agertzen 
diren orokorrak izango dira, gorago aipatu ditugunak, lan elkartuko kooperatiba komentatzerakoan.

Nolanahi ere, kooperatiba txikiak gehienez bost soldatapeko langile kontrata ditzake.

\section{Kooperatiben arteko kooperazioa: kooperatiben asoziazionismoa eta integrazioa}

Arlo honi dagokionez, EKLaren berrikuntza nabarmenenak kooperatiben integrazioari dagozkio ${ }^{33}$. Hala, alde batetik kooperatiba-korporazioak, administrazio sistema dualista bat zutenak, desagertzea azpimarratu behar da, izan ere, haien arauketa baliagarria izan dela ulertzen den arren, gaur egun mugatzailea izan daiteke, EKLren zioen azalpenaren arabera. Figura hau euskal legegileak sortu zuen Arrasateko kooperatiben arteko kooperazioak planteatzen zituen antolakuntza beharrei erantzuteko asmoz, doktrinaren zati batek beharrezkoa ez zela ulertzen zuen arren, bigarren eta hurrengo mailako kooperatiben arauketa zabala kontuan izanda ${ }^{34}$.

Bestalde, Erregelamenduan jasotako kooperatiba-taldeen arauketa EKLan barneratzen da. Honela, legeak integrazio ekonomikoaren mailaren arabera integrazio bidezko eta lankidetza bidezko kooperatiba-taldeak bereizten ditu, lehenengoetan taldeko kooperatiba guztientzat zuzendaritza orokor bat egongo delarik, eta baita kooperatiben artean benetako batasun ekonomikoa ${ }^{35}$ (154.2 art.). Gai honen inguruko arauketan sakondu gabe, edozein kasutan kooperatiben arteko kooperazio-egiturek printzipio kooperatiboak errespetatu behar dituzte (EKLak espresuki aitortzen du

33 Kooperatiben arteko asoziazionismoari dagokionez, 4/1993 Legearen arauketa laburra mantentzen da, kooperatiben federazio eta konfederazioek haien izenean «Euskadiko» barneratzearen beharrari dagokionez egokitzapen txikien kalterik gabe (164.2 eta 3 art.).

${ }^{34}$ Horren inguruan (eta orokorrean, kooperatiben integrazio-ereduen inguruan), Alfonso Sánchez (2000, bereziki 179-180 eta 297-299 orr.).

35 EKL 154.3 artikuluaren arabera, batasun ekonomikoa dagoela ulertzeko hurrengo egoeretariko bat eman beharko da gutxienez: a) Egitatezko merkataritza-, finantza-edo ondare-harremanak egotea, zeinak benetan taldeko entitateren baten mende egotea eragingo duen. b) Taldeko kooperatibek hirugarren ez-bazkideekin zuzenean egiten dituzten eragiketak direla-eta, erantzukizun solidarioko akordio bat izatea kanpoarekiko; betiere, eragiketa horiek iraunkorrak eta beharrezkoak -ez osagarriak - badira enpresa-jarduerarako. c) Konpromisoa izatea aldian-aldian baliabide-ekarpena egiteko nork bere kooperatibaren emaitza-kontuen arabera, betiere egin beharreko ekarpenak kooperatiba bakoitzaren aurreko soberakin garbien ehuneko berrogeita hamar baino gehiago badira. d) Kooperatiba-taldeko bi sozietatek edo gehiagok harremanak izatea beren artean, eta, harreman horien bidez, kontuak finkatzeko betebeharra sortzea, Merkataritza Kodearen 42.1 eta 43. artikuluetan arautzen den bezala. Kasu hauetakoren bat bakarrik gertatzen bazaie taldeko kooperatiba batzuei, sozietate kooperatibo horiek bakarrik joko dira integrazio bidezko kooperatiba-talde bateko kidetzat. 
154.1 artikuluan), bereziki bazkideek kontrol demokratikoa mantentzea eta beste erakundeekiko autonomia. Horregatik, batasun ekonomiko bat eta zuzendaritza orokor bat egotea posible den arren, ezin dira onartu kooperatibak hierarkikoki beste erakunde baten menpe (hau kooperatiba izan zein ez) geratzea dakarten egiturak; EKLak batasun ekonomikoa dagoela ulertzeko jasotzen dituen kasuetariko batzuk honekin talka egin dezakete.

\section{Kooperatibak eta Administrazio publikoa}

Kooperatibekiko garatzen den jarduera publikoa gidatu behar duen printzipio gisa, legeak ondokoa dio: Euskal Autonomia Erkidegoko botere publikoek beren gain hartzen dute, interes sozialeko funtzio modura, kooperatibak eurak eta kooperatibek enpresa integratu eta ordezkatzeko dituzten egiturak sustatu, bizkortu eta garatzeko lana. (art. 156.1).

Mugimendu kooperatiboaren solaskidea legitimoa nor izango den zehazten du ere legeak: betiere enpresen ordezkagarritasunari buruz indarren dauden erregelak eragotzi gabe, Euskadiko Kooperatiben Erregistroan inskribatuta dauden eta jarduera egiaztatuta duten kooperatiben ehuneko hirurogei baino gehiago elkartzen duen entitatea (art. 156.1 art.).

Esanguratsua dirudi legegileak planteatzen duen elkarlana sektore publikoa eta sektore kooperatiboaren artean, hauxe dioenean, Euskal Autonomia Erkidegoko botere publikoek kooperatibak sortzea eta haiek zerbitzu publikoen kudeaketan parte hartzea bultzatuko dute, zerbitzu publikoak garatzeko eta hobetzeko (art. 157.3 art.).

Baita ere, legeak kooperatibek egin ditzaketen arau-hausteak eta jaso ditzaketen zehapenak jasotzen ditu (158-162 art.), kooperatiben ikuskaritza lan arloan eskumena duen Eusko Jaurlaritzaren sailari egotziz.

Bestalde, legeak dio administrazio publikoak kooperatiben asoziazionismoa bultzatu behar duela, euskal kooperatibismoa egituratzeko, era horretan Euskal Autonomia Erkidegoko kooperatiba-mugimendua osatzen dute hala kooperatibek nola kooperatiba-batasunek, -federazioek eta-konfederazioek eta Euskadiko Kooperatiben Goren Kontseiluak (163.2 art.).

\section{Euskadiko Kooperatiben Goren Kontseilua}

Legeak Euskadiko Kooperatiben Goren Kontseilua erregulatzen du, entitate berezi gisa, izaera publikoa duena, kooperatibismoa sustatzeko eta haren berri zabaltzeko organo goren gisa sortua, euskal administrazio publiko guztientzako kontsulta- eta aholku-entitate publiko gisa eratzen da kooperatibismoaren inguruko gai guztietan (165.1 art.). 
Kontseiluko kideak dira Eusko Jaurlaritza, Kontseiluan gehiengoa duen Euskadiko Kooperatiben Konfederazioa (Konfekoop), Euskal Autonomi Erkidegoko hiru unibertsitateak, eta, EKLak ekarri dituen kide berriak, hiru Foru Aldundiak.

Positiboki baloratzen dugu Foru Aldundiak EKGKn sartzea, Kontseilua indartzeko, Aldundiek eskumen garrantzitsuak dituztelako, batez ere fiskalitatearen alorrean, esparru horretan Aldundi bakoitzak erabateko eskumena baitauka.

EKGKren funtzioen artean arbitraje kooperatiboa dago. Gai honetan berrikuntza bat dago, kooperatibaren barne bidea agortzeko beharra, gatazka dagoenean kooperatiba eta bere bazkideen artean, ondoren arbitrajera jo ahal izateko.

\section{Ondorioak}

Esandako guztiagatik, ongi etorria eman behar diogu Euskadiko Kooperatiben Lege berriari, jasotzen dituen hobekuntza teknikoengatik, eta egin dituen aldaketa batzuengatik. Azpimarratuko genuke, ondoren esaten dugunaren kalterik gabe, Nazioarteko Aliantza Kooperatiboaren printzipioei egiten dien aipamena; genero berdintasuna sustatzeko aurreikuspenak; bazkideen eskubideak bermatzeko ezartzen diren neurriak; bazkideek kooperatibaren organoetan parte hartzea errazteko neurriak; administratzaileen betebeharren arauketaren garapena eta hobekuntza; bazkideen erantzukizunaren araubidea argitzea; kooperatiba mota berriak aurreikustea; lehendik zeuden batzuk legez garatzea; edo lan elkartuko kooperatibetan lan baldintza duinak egoteko eta Lanaren Nazioarteko Erakundeko gutxieneko estandar laboralak errespetatzeko aipamen berriak.

Baina, aurreko orrialdeetan azaldu dugun moduan, badaude lege berrian hainbat elementu eztabaidagarri eta kritikagarri, egin diren aldaketei edo egin ez direnei dagokienez, izan ere batzuetan kooperatibaren esentziatik zerbait urruntzea ekarri dute, eta beste askotan aldaketak motz geratu dira, lege berriaren azkerteka sakonago bat eginda seguruenik ere ageriago izango litzatekeena. Lege berri bat onartzeko prozedura kontuan izanda, faltan bota da araututako elementu batzuetan gehiago eragiteko borondatea.. Hala nola genero berdintasunari edo kooperatiben organoei dagozkien zenbait aspektu, edo lan elkartuko kooperatibetan soldatapeko langileak kontratatzeko gehiegizko malgutasuna. 


\section{Bibliografia}

Alfonso Sánchez, Rosalía (2000). La integración cooperativa y sus técnicas de realización: la cooperativa de segundo grado. Valentzia: Tirant lo Blanch.

Bengoetxea Alkorta, Aitor (2019). Employment in worker cooperatives in the framework of Spanish cooperative law. International Journal of Cooperative Law, II, 72-87.

De Nieves Nieto, Nuria (2005). Cooperativas de Trabajo Asociado: Aspectos Juridico-Laborales. Madril: Consejo Económico y Social.

Elio Cemborain, Eunate (2006). Responsabilidad social en las cooperativas: igualdad de oportunidades entre hombres y mujeres. Gizarte Ekonomiaren Euskal Aldizkaria - Revista Vasca de Economía Social, 2, 35-71.

Fernández Abella, José María (2018). ¿Es posible la reactivación de una sociedad en fase de liquidación a resultas del abono de los créditos concursales?. LegalToday, 2018ko otsailaren 21a. http://www.legaltoday.com/blogs/sociedades/ blog-affectio-societatis/es-posible-la-reactivacion-de-una-sociedad-en-fase-deliquidacion-concursal-a-resultas-del-abono-de-los-creditos-concursales

Gadea Soler, Enrique (2012). La determinación del resultado y la distribución de los excedentes o la imputación de pérdidas del ejercicio económico en las sociedades cooperativas. Revista de Derecho de Sociedades, 39, 257-280.

García Álvarez, Belén (2015). La retribución de los miembros del consejo rector o de los administradores en las sociedades cooperativas. REVESCO, 119, 53-76.

Grimaldos García, María Isabel (2013). La responsabilidad civil de los administradores de entidades de economía social. Gómez, M.F. eta Pardo, M.M., Economía social y Derecho. Problemas juridicos actuales de las empresas de economía social (67-93). Granada: Comares.

Irastorza Martínez, Irantzu eta López Lolo, Raquel (2020). Acercamiento del régimen de las sociedades cooperativas al de las sociedades de capital. ¿Un cambio necesario para el futuro del modelo cooperativo?. Diario La Ley, 9582, 2020ko otsailaren 26a.

López Gandía, Juan (2006). Las cooperativas de trabajo asociado y la aplicación del Derecho del Trabajo. Valentzia: Tirant lo Blanch.

Martínez Balmaseda, Arantza (2014). Algunos aspectos jurídico-mercantiles tras el concurso de Fagor. CIRIEC-España, Revista jurídica de economía social y cooperativa, 25, 281-312.

Senent Vidal, María José (2011). Principios cooperativos, género y RSE. Cuadernos mujer y cooperativismo, 13, 5-32.

Suso Vidal, Jose María (2013). El concurso de la sociedad cooperativa. J.I. Peinado Gracia (zuz.), Tratado de Derecho de Cooperativas. Tomo II. Valentzia: Tirant lo Blanch. 1551-1574.

Villafáńez Pérez, Itziar (2014): Cooperativa y concurso. Estudio de las relaciones juridicas con sus socios. Madril: Marcial Pons.

Villafáñez Pérez, Itziar (2016). El deber de lealtad y sus concreciones en la legislación cooperativa. REVESCO, 120, 121-148. 
Villafáñez Pérez, Itziar (2017). Principios y valores cooperativos, igualdad y género e interés social en las cooperativas. CIRIEC-España, Revista jurídica de economía social y cooperativa, 30, 47-83.

Viteri Zubia, Ibon (2016). La responsabilidad del socio cooperativista por las pérdidas sociales. CIRIEC-España, Revista jurídica de economía social y cooperativa, 28, 209-245. 